\title{
Patient-identified quality indicators for colonoscopy services
}

\author{
Maida J Sewitch $\mathrm{PhD}^{1,2}$, Catherine Dubé MD MSc FRCPC ${ }^{3}$, Stephanie Brien $\mathrm{MSc}^{2}$, \\ Mengzhu Jiang MSc${ }^{2}$, Robert J Hilsden MD PhD FRCPC ${ }^{3}$, Alan N Barkun MD CM MSc ${ }^{1}$, \\ David Armstrong MA MB BChir FRCP(UK) FACG AGAF FRCPC ${ }^{4}$
}

\begin{abstract}
MJ Sewitch, C Dubé, S Brien, et al. Patient-identified quality indicators for colonoscopy services. Can J Gastroenterol 2013;27(1):25-32.

BACKGROUND: Current quality improvement tools for endoscopy services, such as the Global Rating Scale (GRS), emphasize the need for patient-centred care. However, there are no studies that have investigated patient expectations and/or perceptions of quality indicators in endoscopy services.
\end{abstract}

OBJECTIVES: To identify quality indicators for colonoscopy services from the patient perspective; to rate indicators of importance; to determine factors that influence indicator ratings; and to compare the identified indicators with those of the GRS.

METHODS: A two-phase mixed methods study was undertaken in Montreal (Quebec), Calgary (Alberta) and Hamilton (Ontario) among patients $\geq 18$ years of age who spoke and read English or French. In phase 1 , focus group participants identified quality indicators that were then used to construct a survey questionnaire. In phase 2, survey questionnaires, which were completed immediately after colonoscopy, prompted respondents to rate the 20 focus group-derived indicators according to their level of importance (low, medium, high) and to list up to nine additional items. Multiple logistic regression analysis was used to determine the factors that influenced focus group-derived indicator ratings. Patient-identified indicators were compared with those used in the GRS to identify novel indicators.

RESULTS: Three quality indicator themes were identified by 66 participants in 12 focus groups: communication, comfort and service environment. Of the 828 surveys distributed, 402 (48.6\%) were returned and $65 \%$ of focus group-derived indicators were rated highly important by at least $55 \%$ of survey respondents. Indicator ratings differed according to age, sex, site and perceived colorectal cancer risk. Of the 29 patient-identified indicators, 17 (58.6\%) were novel.

CONCLUSIONS: Patients identified 17 novel quality indicators, suggesting that patients and health professionals differ in their perspectives with respect to quality in colonoscopy services.

Key Words: Colorectal cancer screening; Indicators; Quality

\section{Les indicateurs de qualité des services de coloscopie selon les patients}

HISTORIQUE : Les outils actuels d'amélioration de la qualité des services d'endoscopie, tels que l'échelle GRS de classement global, font ressortir la nécessité d'axer les soins sur les patients. Cependant, aucune étude ne porte sur les attentes des patients ou les perceptions des indicateurs de qualité au sein des services d'endoscopie.

OBJECTIFS : Déterminer les indicateurs de qualité des services d'endoscopie selon le point de vue des patients, évaluer les indicateurs d'importance, déterminer les facteurs qui influent sur le classement des indicateurs et comparer les indicateurs relevés avec ceux de la GRS.

MÉTHODOLOGIE : Les chercheurs ont entrepris une étude à méthodologie mixte en deux phases à Montréal (Québec), Calgary (Alberta) et Hamilton (Ontario) chez des patients d'au moins 18 ans qui parlaient et lisaient l'anglais ou le français. Pendant la phase 1, les participants au groupe de travail ont déterminé des indicateurs de qualité, qui ont ensuite été utilisés pour préparer un questionnaire. Pendant la phase 2, les questionnaires, remplis immédiatement après une coloscopie, invitaient les répondants à classer les 20 indicateurs dérivés du groupe de travail d'après leur niveau d'importance (faible, moyen, élevé) et à relever jusqu'à neuf autres points. Les chercheurs ont utilisé l'analyse de régression logistique pour déterminer les facteurs qui influaient sur le classement des indicateurs dérivés du groupe de travail. Ils ont ensuite comparé les indicateurs relevés par les patients à ceux utilisés dans l'échelle GRS pour déterminer les nouveaux indicateurs.

RÉSULTATS : Les 66 participants à 12 groupes de travail ont relevé trois thèmes : la communication, le confort et le service. Sur les 828 sondages distribués, 402 (48,6\%) ont été remplis et au moins $55 \%$ des répondants au sondage ont qualifié $65 \%$ des indicateurs dérivés du groupe de travail d'une importance élevée. Les classements des indicateurs différaient selon l'âge, le sexe, le lieu et le risque perçu de cancer colorectal. Sur les 29 indicateurs déterminés par les patients, 18 (62,1\%) étaient nouveaux, et 13 , quatre et un étaient liés aux thèmes du service, de la communication et du confort, respectivement.

CONCLUSIONS : Les patients ont relevé 18 nouveaux indicateurs de la qualité, ce qui laisse supposer que le point de vue des patients et des professionnels de la santé diffère à l'égard de la qualité des services de coloscopie.

the care they receive $(6,9,10)$. Although quality assessment programs address structural and performance measures, outcome measures that assess the patient experience have not been well studied $(11,12)$ despite the recognition that they are crucial to improving the quality of care that patients value $(6,9)$.

The Canadian Association of Gastroenterology (CAG) developed a multifaceted Quality Program in Endoscopy that addresses structural issues, such as procedural wait times $(13,14)$ and credentialing $(15,16)$, and performance measures such as adenoma detection rates (17-20). Central to the CAG program is the Global Rating Scale (GRS), an endoscopy quality-improvement tool that was developed in the

health care quality movement is underway in Canada that is
aimed at improving the quality of delivered health care, reducing
the variability in the standard of care (1-3), and reducing the large
gaps that exist between expected and delivered health care $(4,5)$.
Quality in health care is defined as the degree to which health services
increase the likelihood for desired health outcomes and are consistent
with current professional knowledge (6). Health care quality is meas-
ured according to structure, process and outcome dimensions $(7,8)$.
Structural measures address the capacity to deliver quality health care.
Process or performance (9) measures address the steps taken in patient
care. Outcome measures address what happens to patients as a result of

${ }^{1}$ Department of Medicine, McGill University; ${ }^{2}$ Research Institute of the McGill University Health Centre, Montreal, Quebec; ${ }^{3}$ Departments of Medicine and Community Health Sciences, University of Calgary, Calgary, Alberta; ${ }^{4}$ Division of Gastroenterology, Department of Medicine, McMaster University, Hamilton, Ontario

Correspondence: Dr Maida J Sewitch, 687 Pine Avenue West, V Building, Room V2.15, Montreal, Quebec H3A 1A1.

Telephone 514-934-1934 ext 44736, fax 514-934-8293, e-mail maida.sewitch@mcgill.ca

Received for publication May 25, 2012. Accepted June 4, 2012 
United Kingdom (UK) to support the provision of high-quality patient-centred care (12). The GRS was developed following meetings with endoscopy staff who identified 12 areas or 'items' that were considered to be important for a patient undergoing endoscopy: six items each (total 12) in the dimensions of 'Quality and Safety' and 'Customer Care'. The GRS affords endoscopy facilities the ability to evaluate the overall quality of endoscopy services on a regular sixmonth schedule and, hence, to evaluate the effects of targeted qualityimprovement interventions. However, although the GRS has been very effective in influencing endoscopy services by assuming a patient perspective, the quality items were defined by health care providers whose views may not be congruent with those of patients (21-23). This may be particularly relevant when the health care providers work in one health care system (eg, UK) and the patients are served by a different system or systems (eg, Canada). Thus, the patient feedback and surveys recommended by the GRS program should be tailored to the specific health care system. Therefore, the present study aimed to identify patient-derived quality indicators for colonoscopy services by understanding aspects of patients' experiences with and perceptions of endoscopy services; rate quality indicators for their relative importance to patients; determine the factors that influence quality indicator ratings; and compare the patient-derived indicators with the UK-GRS items.

\section{Study design and sites}

\section{METHODS}

A two-phase study that incorporated qualitative and quantitative data collection and analysis was undertaken at the McGill University Health Centre (MUHC) in Montreal, Quebec, the Forzani-MacPhail Colon Cancer Screening Centre in Calgary, Alberta, and McMaster University Medical Centre in Hamilton, Ontario (2009 to 2011). The endoscopy facilities at the academic institutions in Montreal and Hamilton provide adult endoscopy services for symptomatic and screening-related indications, while the facility in Calgary is dedicated to colorectal cancer (CRC) screening. Phase 1 consisted of patient focus groups and phase 2 consisted of a cross-sectional study. Ethics approval was granted by the Psychiatry/Psychology Research Ethics Board at the MUHC, the Research Ethics Board at Hamilton Health Sciences, McMaster University and the Conjoint Health Research Ethics Board at the University of Calgary, Calgary, Alberta.

\section{Phase 1: Focus groups}

Study population: Study gastroenterologists and nurses assisted with patient recruitment by determining interest in study participation. In Montreal and Hamilton, the research assistant was given patient names and telephone numbers; she would call, explain the study and invite individuals to participate in one focus group session. In Calgary, patients were recruited following the routine colonoscopy information session. Eligible individuals were $\geq 18$ years of age and fluent in English or French, and had undergone or were scheduled to undergo a colonoscopy, with or without previous experience with colonoscopy (recent or remote).

Data collection methods: Based on expert opinion, a blueprint (Appendix A) that considered an individual's pathway through the system was developed to determine what may be important to an individual undergoing a colonoscopy. Subsequently, a standardized focus group guide, which also drew areas of inquiry from the published literature, was developed. At the focus group discussions, trained facilitators introduced topics and guided the discussion by directing participants to discuss aspects of the colonoscopy procedure or service that they considered to be important to the quality of patient care according to each phase of the procedure (ie, before, during and after colonoscopy). The $60 \mathrm{~min}$ to $90 \mathrm{~min}$ discussions were audiotaped and transcribed verbatim. Facilitators took brief field notes during the discussions and recorded comprehensive field notes within $24 \mathrm{~h}$ of the discussions to capture impressions and main themes. Indicators that were identified in one group were repeated and tested for their relevance in subse- quent focus groups. Written informed consent was obtained from participants before the focus group discussions began.

Data analysis: Audiotapes were analyzed using the constant comparative approach developed by Glaser and Strauss (24). A constant comparative thematic content analysis guided the data analysis. The focus group facilitator and at least one study investigator independently read all transcripts, and identified emerging and recurrent themes and indicators. Similar themes identified across focus groups were compared and additional codes for newly emerging topics were created. Team consensus (investigators: MS, CD; qualitative researchers: JS, KL) was used to develop the major themes and focus group-derived indicators, reduce data into these categories and select the exemplar quotations illustrating each indicator.

\section{Phase 2: Patient survey}

Study population: Eligible individuals were $\geq 18$ years of age, fluent in English or French, and had undergone colonoscopy.

Data collection methods: Individuals were approached at discharge from the colonoscopy recovery area by the research assistant who explained the study and distributed an envelope with the study materials (invitation letter, consent form, anonymous self-administered questionnaire, postage-paid envelope) to interested patients. The questionnaire comprised two sections: an indicator rating section and an open-ended statements section. The indicator rating section included the 20 focus group-derived indicators. Respondents were asked to rate each indicator according to level of importance (low, medium or high). The open-ended statements section contained three questions that asked individuals to list up to three aspects of their colonoscopy experience that they considered to be most important according to phase: before, during, after the colonoscopy. Survey participants could either choose from the 20 focus group-derived indicators or they could record additional items that were relevant to their personal experiences. Data were also collected on age, sex, perceived personal CRC risk (low, moderate, high) and overall colonoscopy experience (satisfactory, unsatisfactory). All study questionnaires were developed in English and forward and back translated into French.

Data analysis: Descriptive statistics characterized the study population overall as well as according to site. Frequencies for each highly rated quality indicator (defined as high versus medium/low importance) were generated and the $\chi^{2}$ test was used to determine differences according to site. Responses to the open-ended questions were classified into existing focus group-derived indicator categories or new categories were created (ie, survey-derived indicators). Team consensus (MS, TE) was used to ensure reproducibility of the classifications. Frequencies were generated overall and according to site for the responses to the open-ended statements that were endorsed by $\geq 10$ survey respondents. Multiple logistic regression was used to determine the factors that influenced focus group-derived indicator ratings. Separate models were generated for each indicator, controlling for age (continuous), sex (female/male), site (Montreal/Calgary) and perceived CRC risk status (low/moderate or high). ORs and 95\% CIs were calculated using SAS version 9.2 (SAS, USA).

The patient-derived indicators were qualitatively compared with the UK-GRS items. Two team members (MS, SB) compiled a list of all patient-derived indicators, merging similar focus group- and surveyderived indicators where appropriate, and compared them with the GRS statements to determine whether the patient-derived indicators had previously been addressed (yes/no). Indicators not addressed in the UK-GRS were considered to be novel indicators.

\section{Phase 1: Focus groups}

\section{RESULTS}

Sixty-six patients participated in 12 focus group discussions consisting of four to eight participants. The median age was 61 years (range 22 to 82 years), 50\% were male and more than one-half (66\%) had undergone a colonoscopy. Three quality themes were identified: communication, comfort and service environment. 
TABLE 1

Exemplars of focus group-derived indicators according to theme

\begin{tabular}{|c|c|}
\hline Theme & Exemplar \\
\hline \multirow[t]{4}{*}{ Communication } & "Find out what could go wrong with the procedure and information like why are they doing it and what are they going to do" \\
\hline & "The relation between the staff of the hospital, doctors and nurses, and the patients is the most important factor of quality" \\
\hline & $\begin{array}{l}\text { "When they give you the results, you're not fully awake and you can't grasp anything. I have to be fully recovered and if I have a question } \\
\text { I don't want to feel pressed for time" }\end{array}$ \\
\hline & $\begin{array}{l}\text { "A number to call for follow-up with some kind of counselling especially when you have complications, I would have liked some kind of } \\
\text { follow-up or feedback from the staff" }\end{array}$ \\
\hline \multirow[t]{4}{*}{ Comfort } & "Pain element is very important; prefer the least amount of pain possible during the procedure" \\
\hline & $\begin{array}{l}\text { "The doctor, the team and the way they speak to you needs to feel comfortable while protecting your dignity because it's a pretty } \\
\text { embarrassing procedure" }\end{array}$ \\
\hline & "You're anxious and it's the doctor and the team that makes the difference" \\
\hline & $\begin{array}{l}\text { "Privacy is really the main issue, when you have that type of a procedure done and you have a lot of gas, it's very embarrassing and the } \\
\text { recovery room is an open room, we need curtains" }\end{array}$ \\
\hline \multirow[t]{6}{*}{ Service environment } & "It's important to know if it's an experienced surgeon or a student who's going to be doing it, that would affect my decision" \\
\hline & "At busier places I don't always feel safe, there could be an error, mix up or something" \\
\hline & "It's important to stay connected to the same specialist when I have the same procedure repeated" \\
\hline & "There's usually a lot of people in the waiting area, I end up waiting in the hallway" \\
\hline & "The recovery room is an open room with no curtains and the staff is just in the middle talking, I just want some privacy to recover" \\
\hline & $\begin{array}{l}\text { "The only thing I don't like about the changing room is when you have to hang your personal stuff with other people's stuff, almost like } \\
\text { sharing lockers" }\end{array}$ \\
\hline
\end{tabular}

Communication encompassed the following seven subthemes:

- clear instructions;

- knowing what to expect;

- patient-physician interactions;

- timely test results;

- contact numbers for information on the procedure;

- access to psychological support following a diagnosis; and

- a mechanism to provide feedback about the service.

Comfort addressed five physical and psychological concerns including the following:

- being treated with dignity and respect;

- adequate pain control;

- adequate sedation;

- treated as an individual; and

- privacy.

Service environment addressed eight aspects of the physical structure of the facility and the delivery of good customer service, including concerns about the following:

- the cosmetic aspects of the:

o wait area;

$\circ$ changing area;

$\circ$ recovery area;

- the presence of nurses during the colonoscopy;

- the flexibility to choose the:

○ bowel preparation;

$\circ$ endoscopist;

o sex of the health care team members in the endoscopy suite; and

o date of the colonoscopy appointment.

These 20 focus group-derived items comprised the indicator rating section of the survey questionnaire that was distributed in phase 2 of the study. Exemplars from the three themes are presented in Table 1.

Phase 2: Patient survey

In total, 828 surveys were distributed $(n=495$ [59.8\%] in Montreal; $\mathrm{n}=333[40.2 \%]$ in Calgary), of which 402 (48.6\%) were returned $(\mathrm{n}=238$ [59.2\%] in Montreal; $\mathrm{n}=164$ [40.8\%] in Calgary). Characteristics of the survey respondents are summarized in Table 2.
TABLE 2

Characteristics of survey respondents $(n=402)$

\begin{tabular}{lccc}
\hline & \multicolumn{2}{c}{ Site } & \\
\cline { 2 - 3 } Characteristic & $\begin{array}{c}\text { Montreal, } \\
\text { Quebec }(\mathbf{n}=238)\end{array}$ & $\begin{array}{c}\text { Calgary, } \\
\text { Alberta }(\mathbf{n = 1 6 4 )}\end{array}$ & Total \\
\hline Age, years, mean \pm SD & $59.6 \pm 11.8$ & $59.9 \pm 9.0$ & $59.7 \pm 10.8$ \\
Sex & & & \\
$\quad$ Female & $124(52.3)$ & $102(62.2)$ & $226(56.2)$ \\
$\quad$ Male & $113(47.7)$ & $62(37.8)$ & $175(43.5)$ \\
Perceived colorectal cancer risk & & & \\
Low & $122(52.6)$ & $84(51.2)$ & $206(52.0)$ \\
Moderate & $87(37.5)$ & $58(35.4)$ & $145(36.6)$ \\
High & $23(9.9)$ & $22(13.4)$ & $45(11.4)$ \\
Overall colonoscopy experience & & & \\
Satisfactory & $229(96.6)$ & $162(99.4)$ & $391(97.8)$ \\
Unsatisfactory & $8(3.4)$ & $1(0.6)$ & $9(2.3)$ \\
\hline
\end{tabular}

Data presented as $n$ (\%) unless otherwise indicated

Table 3 presents the proportions of survey participants who rated the 20 focus group-derived indicators as highly important. More than $80 \%$ of participants rated four communication items (clear instructions, detailed information, knowing what to expect, obtaining results in a timely manner) and five comfort items (dignity, treated with respect, staff attitude, treat me as an individual, pain control) as highly important. In comparison, fewer participants rated service environment indicators as highly important, although three (recovery area, presence of nurses during procedure and bowel preparation options) were rated highly important by more than $55 \%$ of participants.

Site differences were noted in the focus group-derived indicator ratings (Table 3). Compared with Montreal, greater proportions of respondents in Calgary rated communication indicators including "clear instructions", "detailed information" and "ability to provide feedback" and comfort indicators "dignity" and "treated with respect" of higher importance; in comparison, greater proportions of patients in Montreal rated "relationship with physician" and the "ability to choose the doctor I want" higher. Table 4 shows that communication indicator ratings were influenced by older age, female sex and site, whereas comfort indicator ratings were influenced primarily by female sex. No systematic differences were found for service environment indicator ratings. 
TABLE 3

Proportions of survey respondents who rated focus group-derived indicators as highly important, overall and according to site

\begin{tabular}{|c|c|c|c|}
\hline \multirow[b]{2}{*}{ Indicator } & \multicolumn{2}{|c|}{ Site } & \multirow[b]{2}{*}{ Total $(n=402)$} \\
\hline & Montreal, Quebec $(n=238)$ & Calgary, Alberta $(n=164)$ & \\
\hline \multicolumn{4}{|l|}{ Communication } \\
\hline Clear instructions* & $205(86.1)$ & $161(98.2)$ & $366(91.0)$ \\
\hline Detailed information, knowing what to expect ${ }^{\dagger}$ & $197(82.8)$ & $151(92.1)$ & $348(86.6)$ \\
\hline Results provided in a timely manner & 195 (81.9) & $141(86.0)$ & $336(83.6)$ \\
\hline Contact number for more information & $160(67.2)$ & $111(67.7)$ & $271(67.4)$ \\
\hline Relationship with physician* & $176(74.0)$ & $74(45.1)$ & $250(62.2)$ \\
\hline Ability to provide feedback about service ${ }^{\ddagger}$ & $89(37.4)$ & $80(48.8)$ & $169(42.0)$ \\
\hline Phone number for psychological support post procedure & $44(18.5)$ & $39(23.8)$ & $83(20.7)$ \\
\hline \multicolumn{4}{|l|}{ Comfort } \\
\hline Dignity, treated with respect ${ }^{\dagger}$ & $215(90.3)$ & $160(97.6)$ & $375(93.3)$ \\
\hline Staff attitude, treat me as an individual & $209(87.8)$ & $153(93.3)$ & $362(90.1)$ \\
\hline Pain control & $195(81.9)$ & $130(79.3)$ & $325(80.9)$ \\
\hline Privacy; example: curtains in recovery area & $169(71.0)$ & $129(78.7)$ & $298(74.1)$ \\
\hline Sedation & $160(67.2)$ & $119(72.6)$ & $279(69.4)$ \\
\hline \multicolumn{4}{|l|}{ Service environment } \\
\hline Recovery area & $153(64.3)$ & $104(63.4)$ & 257 (63.9) \\
\hline Presence of nurses during procedure & $153(64.3)$ & $100(61.0)$ & $253(62.9)$ \\
\hline Options for preparation & $132(55.5)$ & $100(61.0)$ & $232(57.7)$ \\
\hline Changing area ${ }^{\ddagger}$ & $100(42.0)$ & $88(53.7)$ & $188(46.8)$ \\
\hline Flexibility in scheduling the appointment & $105(44.1)$ & $82(50.0)$ & $187(46.5)$ \\
\hline Wait area & $91(38.2)$ & $65(39.6)$ & $156(38.8)$ \\
\hline Ability to choose the doctor I want* & $123(51.7)$ & $26(15.9)$ & $149(37.1)$ \\
\hline Sex of health team members & $69(29.0)$ & $46(28.1)$ & $115(28.6)$ \\
\hline
\end{tabular}

Data presented as $n$ (\%). ${ }^{*} P<0.001$ ( $\chi^{2}$ testing for site differences); ${ }^{\dagger} P<0.01 ;{ }^{\ddagger} P<0.05$

\section{TABLE 4}

Multivariate logistic regression results for focus group-derived quality indicators rated highly important

\begin{tabular}{|c|c|c|c|c|}
\hline \multirow[b]{2}{*}{ Indicator } & \multicolumn{4}{|c|}{ Factor } \\
\hline & $\begin{array}{c}\text { Age: } \\
5 \text { years }\end{array}$ & $\begin{array}{c}\text { Sex: } \\
\text { Female versus male }\end{array}$ & $\begin{array}{l}\text { Site: Montreal, Quebec } \\
\text { versus Calgary, Alberta }\end{array}$ & $\begin{array}{c}\text { Risk: Low or moderate } \\
\text { versus high }\end{array}$ \\
\hline \multicolumn{5}{|l|}{ Communication } \\
\hline Clear instructions & $1.17(1.01-1.36)$ & $0.53(0.26-1.11)$ & $7.62(2.28-25.53)$ & $1.09(0.31-3.87)$ \\
\hline Detailed information, knowing what to expect & $1.10(0.97-1.25)$ & $0.57(0.31-1.02)$ & $2.20(1.13-4.28)$ & $2.08(0.61-7.07)$ \\
\hline Results provided in a timely manner & $1.17(1.03-1.33)$ & $0.52(0.30-0.93)$ & $1.06(0.59-1.91)$ & $1.78(0.61-5.26)$ \\
\hline Contact number for more information & $1.12(1.01-1.23)$ & $0.43(0.28-0.67)$ & $0.86(0.55-1.34)$ & $0.90(0.45-1.81)$ \\
\hline Relationship with physician & $1.17(1.05-1.29)$ & $1.12(0.72-1.75)$ & $0.26(0.17-0.41)$ & $3.09(1.39-6.85)$ \\
\hline Ability to provide feedback about service & $1.13(1.03-1.25)$ & $1.11(0.73-1.69)$ & $1.55(1.02-2.36)$ & $1.54(0.81-2.94)$ \\
\hline Phone number for psychological support postprocedure & $1.16(1.03-1.32)$ & $0.67(0.40-1.13)$ & $1.33(0.80-2.19)$ & $1.11(0.51-2.39)$ \\
\hline \multicolumn{5}{|l|}{ Comfort } \\
\hline Dignity, treated with respect & - & - & - & - \\
\hline Staff attitude, treated me as an individual & $0.96(0.82-1.13)$ & $0.59(0.30-1.18)$ & $1.63(0.78-3.42)$ & $2.18(0.50-9.44)$ \\
\hline Pain control & $0.91(0.81-1.04)$ & $0.53(0.31-0.89)$ & $0.79(0.47-1.33)$ & $1.76(0.66-4.68)$ \\
\hline Privacy; example: curtains in recovery area & $0.96(0.87-1.07)$ & $0.56(0.36-0.89)$ & $1.47(0.91-2.37)$ & $0.46(0.24-0.90)$ \\
\hline Sedation & $0.91(0.82-1.01)$ & $0.50(0.31-0.78)$ & $1.06(0.67-1.68)$ & $1.65(0.73-3.75)$ \\
\hline \multicolumn{5}{|l|}{ Service environment } \\
\hline Recovery area & $1.08(0.98-1.19)$ & $0.66(0.43-1.01)$ & $0.85(0.56-1.31)$ & $1.21(0.60-2.44)$ \\
\hline Presence of nurses during procedure & $1.04(0.95-1.15)$ & $0.48(0.32-0.74)$ & $0.78(0.51-1.19)$ & $1.83(0.88-3.78)$ \\
\hline Options for preparation & $1.07(0.97-1.18)$ & $1.05(0.69-1.60)$ & $1.22(0.80-1.86)$ & $1.55(0.78-3.11)$ \\
\hline Changing area & $1.07(0.97-1.17)$ & $0.81(0.54-1.22)$ & $1.55(1.03-2.32)$ & $1.04(0.55-1.98)$ \\
\hline Flexibility in scheduling the appointment & $0.96(0.88-1.06)$ & $1.04(0.69-1.55)$ & $1.33(0.88-1.99)$ & $1.04(0.55-1.97)$ \\
\hline Waiting area & $1.06(0.96-1.16)$ & $1.01(0.67-1.52)$ & $1.02(0.67-1.53)$ & $1.51(0.80-2.84)$ \\
\hline Ability to choose the doctor I want & $1.28(1.15-1.44)$ & $1.00(0.63-1.59)$ & $0.16(0.10-0.27)$ & $1.57(0.74-3.31)$ \\
\hline Sex of health team members & $1.03(0.92-1.14)$ & $0.63(0.40-1.01)$ & $0.77(0.49-1.22)$ & $2.07(1.03-4.14)$ \\
\hline
\end{tabular}

Data presented as adjusted OR (95\% Cl). Values in bold are statistically significant 


\begin{tabular}{|c|c|c|c|}
\hline \multirow[b]{2}{*}{ Statements } & \multicolumn{2}{|c|}{ Site } & \multirow[b]{2}{*}{ Total $(n=402)$} \\
\hline & $\begin{array}{l}\text { Montreal, Quebec } \\
\qquad(n=238)\end{array}$ & $\begin{array}{l}\text { Calgary, Alberta } \\
\qquad(n=164)\end{array}$ & \\
\hline \multicolumn{4}{|l|}{ Before arrival at colonoscopy unit } \\
\hline Clear instructions on preparation, information on side effects & $93(39.1)$ & $81(49.4)$ & $174(43.3)$ \\
\hline Detailed information on knowing what to expect on day of/during procedure & $46(19.3)$ & $55(33.5)$ & $101(25.1)$ \\
\hline Options for preparation & $55(23.1)$ & $32(19.5)$ & $87(21.6)$ \\
\hline Convenient booking date and time, scheduling flexibility & $45(18.9)$ & $15(9.1)$ & $60(14.9)$ \\
\hline Contact number for more information/questions, with response & $26(10.9)$ & $14(8.5)$ & $40(10.0)$ \\
\hline Short wait time before initial visit & $9(3.8)$ & $14(8.5)$ & $23(5.7)$ \\
\hline Seating, clean environment/facility: Reception & $12(5.0)$ & $0(0.0)$ & $12(3.0)$ \\
\hline Explicit directions on hospital/colonoscopy unit location & $2(0.8)$ & $8(4.9)$ & $10(2.5)$ \\
\hline Helpful staff/good service & $10(4.2)$ & $0(0.0)$ & $10(2.5)$ \\
\hline \multicolumn{4}{|l|}{ On the day of the colonoscopy } \\
\hline $\begin{array}{l}\text { Preprocedure orientation/clear instructions/details on what to expect when I go to } \\
\text { procedure/meet the nurse or doctors for explanations of preparation, procedures }\end{array}$ & $59(24.8)$ & $75(45.7)$ & $134(33.3)$ \\
\hline Professionalism/courtesy of staff and nurses & $78(32.8)$ & $52(31.7)$ & $130(32.3)$ \\
\hline Results provided on day of procedure & $65(27.3)$ & $35(21.3)$ & $100(24.9)$ \\
\hline Adequate pain control/sedation & $55(23.1)$ & $34(20.7)$ & $89(22.1)$ \\
\hline Procedure performed in timely manner on arrival at unit & $31(13.0)$ & $46(28.0)$ & $77(19.2)$ \\
\hline Dignity, treated with respect and compassion & $20(8.4)$ & $40(24.4)$ & $60(14.9)$ \\
\hline Seating, clean environment/facility: Wait area & $56(23.5)$ & $4(2.4)$ & $60(14.9)$ \\
\hline Quality nursing care & $7(2.9)$ & $33(20.1)$ & $40(10.0)$ \\
\hline Physician and/or staff reduced anxiety & $14(5.9)$ & $12(7.3)$ & $26(6.5)$ \\
\hline Privacy & $8(3.4)$ & $14(8.5)$ & $22(5.5)$ \\
\hline \multicolumn{4}{|l|}{ After the procedure } \\
\hline Contact number for more information/questions, with response & $42(17.6)$ & $26(15.9)$ & $68(16.9)$ \\
\hline Recovery area: Allowed to rest/comfortable recovery & $40(16.8)$ & $8(4.9)$ & $48(11.9)$ \\
\hline Information on possible side effects of colonoscopy and what to do & $21(8.8)$ & $26(15.9)$ & $47(11.7)$ \\
\hline Follow-up (eg, telephone call from the clinic the next day) & $13(5.5)$ & $4(2.4)$ & $17(4.2)$ \\
\hline Staff attitude, treated me as an individual & $24(10.1)$ & $0(0.0)$ & $24(6.0)$ \\
\hline Food availability & $10(4.2)$ & $10(6.1)$ & $20(5.0)$ \\
\hline Assurance that I had high-quality care & $0(0.0)$ & $18(11.0)$ & $18(4.5)$ \\
\hline Meet the doctor to discuss procedure, results, medication & $10(4.2)$ & $0(0.0)$ & $10(2.5)$ \\
\hline Ability to provide feedback about the service & $9(3.8)$ & $1(0.6)$ & $10(2.5)$ \\
\hline
\end{tabular}

Data presented as $n(\%)$

Nine open-ended statements were endorsed by $\geq 10$ survey respondents. Table 5 presents the proportions of survey respondents who endorsed the nine statements. Table 6 presents the 29 (20 from the focus groups and nine from the survey open-ended statements) patient-derived indicators, of which 17 (58.6\%) were novel; according to theme, these included 13 service environment, four communication and one comfort.

\section{DISCUSSION}

We used focus groups and survey methodologies to identify and rate patient-derived colonoscopy quality indicators. We determined the factors that influenced indicator ratings and identified novel indicators by comparing our indicators with those used in the UK-GRS. In total, 29 patient-derived colonoscopy quality indicators were identified, of which 17 were novel. Survey findings supported the focus group findings in that $65 \%$ of the focus group-derived indicators were rated highly important by at least $55 \%$ of survey respondents. More than $80 \%$ of participants rated four communication items (clear instructions, detailed information, knowing what to expect and obtaining results in a timely manner) and five comfort items (dignity, treated with respect, staff attitude, treat me as an individual and pain control) as highly important. Communication and comfort indicator ratings differed according to patient age, sex and site, but there were no systematic differences in service environment indicator ratings.
Site differences in quality indicator ratings may result from the diversity in the two models of colonoscopy service delivery in Calgary and Montreal. In Calgary, Forzani-MacPhail Colon Cancer Screening Centre exclusively provides CRC screening-related colonoscopy services (25) and offers a comprehensive preprocedural patient education program, whereas in Montreal, the MUHC provides full endoscopy services, including those for patients (both ambulatory and hospitalized) with symptoms and/or abnormal test results. Site differences underscore the individuality of endoscopy units and the need for routine patient surveys because the needs and perceptions of patients may vary according to the model of care delivery, sex, age group and indication for the procedure.

In considering quality indicators, patients focused more on what happened leading up to the colonoscopy than on the possible complications of colonoscopy. Items such as obtaining results, knowing what to expect, having clear instructions, good pain control and being treated with dignity were rated of greater importance compared with knowing what to do if complications were experienced. Two systematic reviews reported similar findings: items including the bowel preparation; feelings of anxiety, embarrassment, vulnerability, anticipation of pain; and fear of finding cancer were the main barriers to undergoing screening colonoscopy $(26,27)$. Findings from both our focus group discussions and the survey revealed that patients were not con- 


\section{TABLE 6}

Quality indicators identified in the focus groups and the survey compared with the United Kingdom Global Rating Scale (UK-GRS) survey

\begin{tabular}{|c|c|}
\hline Indicator & $\begin{array}{l}\text { Addressed } \\
\text { in UK-GRS }\end{array}$ \\
\hline \multicolumn{2}{|l|}{ Communication } \\
\hline \multicolumn{2}{|l|}{ Focus group-derived indicators } \\
\hline $\begin{array}{l}\text { Clear instructions on preparation, information on } \\
\text { side effects }\end{array}$ & Yes \\
\hline $\begin{array}{l}\text { Detailed information on knowing what to expect } \\
\text { on day of/during procedure }\end{array}$ & Yes \\
\hline Results provided on day of procedure & Yes \\
\hline Ability to provide feedback about the service & Yes \\
\hline \multicolumn{2}{|l|}{ Survey-derived indicators } \\
\hline Contact number for more information, with response & Yes \\
\hline Physician and/or staff reduced anxiety & No \\
\hline $\begin{array}{l}\text { Follow-up (eg, telephone call from the clinic the next } \\
\text { day)/meet the doctor to discuss, procedure, } \\
\text { results, medication }\end{array}$ & Yes \\
\hline $\begin{array}{l}\text { Preprocedure orientation/meeting with the nurse or } \\
\text { doctors for explanations on procedures }\end{array}$ & No \\
\hline $\begin{array}{l}\text { Information on possible side effects of colonoscopy } \\
\text { and what to do }\end{array}$ & Yes \\
\hline $\begin{array}{l}\text { Explicit directions on hospital/colonoscopy unit } \\
\text { location }\end{array}$ & No \\
\hline \multicolumn{2}{|l|}{ Comfort } \\
\hline \multicolumn{2}{|l|}{ Focus group-derived indicators } \\
\hline Dignity: treated with respect & Yes \\
\hline Staff attitude: treated me as an individual & No \\
\hline Adequate pain control/sedation & Yes \\
\hline Privacy & Yes \\
\hline \multicolumn{2}{|l|}{ Service environment } \\
\hline \multicolumn{2}{|l|}{ Focus group-derived indicators } \\
\hline Recovery area: Allowed to rest/comfortable recovery & No \\
\hline Presence of nurses during procedure & No \\
\hline Options for preparation & No \\
\hline Changing area & No \\
\hline Flexibility in scheduling the appointment & Yes \\
\hline $\begin{array}{l}\text { Seating, clean environment/facility: Wait and } \\
\text { reception area }\end{array}$ & No \\
\hline Ability to choose the doctor I want & No \\
\hline Sex of members of the health team & No \\
\hline \multicolumn{2}{|l|}{ Survey-derived indicators } \\
\hline Professionalism/courtesy of staff and nurses & No \\
\hline $\begin{array}{l}\text { Procedure performed in timely manner on arrival } \\
\text { at unit }\end{array}$ & No \\
\hline Short wait time before initial visit & Yes \\
\hline Helpful staff/good service & No \\
\hline Quality nursing care & No \\
\hline Food availability & No \\
\hline Assurance that I had high-quality care & No \\
\hline
\end{tabular}

cerned with safety, presumably because safety was assumed to be monitored by regulatory bodies. As one focus group participant indicated:
I'm sure they have a safety department that checks the equipment is up to date and clean. And the doctors must have to show they are keeping their skills up to date; this does not worry me. It's a major hospital; they have to have standards or they would be in trouble.

Some of our patient-derived indicators were present in the GRS, while those that were not present were categorized under the three themes of communication, comfort and service environment. Although the GRS includes 'choice' as a quality determinant, it relates solely to scheduling the colonoscopy, whereas the present study revealed that patients also want choice in other areas of the service such as the bowel preparation. In fairness to the developers of the GRS, colonoscopy quality indicators were addressed from the service delivery perspective. Our findings provide partial validation for the GRS as a measure of patient-defined quality and suggest that endoscopy staff and patients value some of the same aspects of colonoscopy services because 12 of the 29 (41.4\%) indicators overlapped. In a comprehensive quality assurance program (28) that also serves to encourage patient compliance $(29,30)$, and positive word-of mouth recommendation (31), we also need to assess and improve the outcomes that are valued by patients $(6,9)$, to assure patients of a safe and satisfactory experience that will not deter them from undergoing appropriate investigation.

Study strengths include the use of both qualitative and quantitative methodologies to identify and rate patient-derived colonoscopy quality indicators. The use of the open-ended survey questions not only permitted validation of the focus group-derived indicators, but also enabled identification of additional indicators not discussed during the focus groups, which will broaden the content of the subsequent questionnaire. Our study also had limitations. First, the survey was prone to selection bias because respondents may have differed from nonrespondents on important variables. Second, focus group moderators differed by city and discrepancies in the conduct of the focus group discussions may have led to information bias. However, this potential was reduced by having the focus group moderator and a coinvestigator review the focus group transcripts and by using team consensus to develop the major themes and patterns. Similarly, categorization of the open-ended statements could have produced different results, although three research staff participated to ensure reproducibility of the classifications.

Given the public health implications of provincial CRC screening programs and the vital role played by and safety profile of colonoscopy, assessment of colonoscopy services quality from the patient perspective is a critical component of endoscopy in general and, more broadly, for digestive health care and health care as a whole. Our future plans are to develop a psychometrically sound, patient-centred colonoscopy/ endoscopy services quality evaluation and improvement tool based on the patient-derived indicators that are applicable to the Canadian health care system and to integrate this tool into the CAG Quality Program in Endoscopy.

ACKNOWLEDGMENTS: This research was supported by an unrestricted grant from the Canadian Digestive Health Foundation. Maida J Sewitch $\mathrm{PhD}$, is a Checheur Boursier Junior 2 of the Fonds de recherche $d u$ Québec-Santé. The authors thank qualitative researchers Kristina Longtin and Javad Shahidi, and research staff Shasha Gong and Talia Erdan.

DISCLOSURES: The authors have no financial disclosures or conflicts of interest to declare. 
APPENDIX A

Blueprint to determine what may be important to an individual undergoing colonoscopy

\begin{tabular}{|c|c|c|c|}
\hline & \multicolumn{3}{|c|}{ Procedure } \\
\hline & Before & During & After \\
\hline \multirow[t]{2}{*}{ Primary care physician } & Impact of test being recommended by GP & & \\
\hline & $\begin{array}{l}\text { Clarity and knowledge for condition and } \\
\text { choice }\end{array}$ & & \\
\hline \multirow[t]{8}{*}{ Endoscopist } & Patient interaction & Patient interaction & Patient interaction \\
\hline & Demeanor & $\begin{array}{l}\text { Discussion about procedure (indications, } \\
\text { benefits, risks, alternatives) }\end{array}$ & Demeanor \\
\hline & $\begin{array}{l}\text { Discussion about procedure (indications, } \\
\text { benefits, risks, alternatives) }\end{array}$ & Discussion during procedure & Discussion about results \\
\hline & Opportunity to ask questions & Opportunity to ask questions & Opportunity to ask questions \\
\hline & & Technical skills & \\
\hline & & Thoroughness & \\
\hline & & Ability to identify/treat lesions & \\
\hline & & Sex of endoscopist & \\
\hline \multirow[t]{5}{*}{ Nurse } & Patient interaction & Patient interaction & Patient interaction \\
\hline & Demeanor & Demeanor & Demeanor \\
\hline & $\begin{array}{l}\text { Opportunity to ask questions and have } \\
\text { them adequately addressed }\end{array}$ & Technical skills & $\begin{array}{l}\text { Opportunity to ask questions and have them } \\
\text { adequately addressed }\end{array}$ \\
\hline & & Intravenous insertion & \\
\hline & & $\begin{array}{l}\text { Explanations, gentleness if applied counter } \\
\text { pressure }\end{array}$ & \\
\hline \multirow[t]{3}{*}{ Clerical and other staff } & Patient interaction & Patient interaction & Patient interaction \\
\hline & Demeanor & Demeanor & Demeanor \\
\hline & Opportunity to ask questions & Opportunity to ask questions & Opportunity to ask questions \\
\hline \multirow[t]{8}{*}{ Physical setting } & Ambiance & Ambiance (eg, music) & Ambiance \\
\hline & Cleanliness & Cleanliness & Cleanliness \\
\hline & Privacy & Ability to watch or not to watch & Privacy \\
\hline & Ease of navigation & & Food/drinks \\
\hline & Privacy & & \\
\hline & Personal & & \\
\hline & Witnessing postprocedure patients & & \\
\hline & Wait with or without relative or friend & & \\
\hline \multirow[t]{8}{*}{ Procedure } & Bowel preparation & Endoscopy & \\
\hline & Instructions & Completeness of the procedure & \\
\hline & Cost & Duration of procedure & \\
\hline & Adverse effects & Safety of procedure & \\
\hline & Palatability & Level of sedation & \\
\hline & Discomfort/vomiting & Number of persons assisting in the room & \\
\hline & Serious side effects & $\begin{array}{l}\text { Experiences of acquaintances who have } \\
\text { undergone the procedure }\end{array}$ & \\
\hline & $\begin{array}{l}\text { Experiences of acquaintances who have } \\
\text { undergone the procedure }\end{array}$ & & \\
\hline \multirow[t]{10}{*}{ System/processes } & Booking options & Safety and security & Booking options \\
\hline & Day/time & Decontamination of instruments & Booked follow-up with endoscopist \\
\hline & Choice of endoscopist & Monitoring of quality and adverse events & \\
\hline & Same-day consult/endoscopy & & \\
\hline & Consent & & \\
\hline & $\begin{array}{l}\text { Timing of consent (before prep taken, day of } \\
\text { procedure) }\end{array}$ & & \\
\hline & $\begin{array}{l}\text { Signing consent inside or outside procedure } \\
\text { room }\end{array}$ & & \\
\hline & Timeliness & Timeliness & Timeliness \\
\hline & $\begin{array}{l}\text { Wait time for consultation or procedure } \\
\text { (if same day) }\end{array}$ & Wait time for procedure & Wait time for follow-up \\
\hline & & Ability to give feedback & Ability to give feedback \\
\hline
\end{tabular}




\begin{tabular}{|c|c|c|c|}
\hline & \multicolumn{3}{|c|}{ Procedure } \\
\hline & Before & During & After \\
\hline \multirow{12}{*}{$\begin{array}{l}\text { Comfort and } \\
\text { convenience }\end{array}$} & Proximity of services & Proximity of services & Proximity of services \\
\hline & Language & Language & Language \\
\hline & & Intravenous insertion & \\
\hline & & Enema & \\
\hline & & Sedation & \\
\hline & & Choice (none, moderate, deep) & \\
\hline & & Adequate & \\
\hline & & Restriction of activities & \\
\hline & & Physical comfort & \\
\hline & & Stretchers & \\
\hline & & Temperature & \\
\hline & Time lost from normal activities & Time lost from normal activities & Time lost from normal activities \\
\hline \multirow[t]{10}{*}{ Receiving information } & Bowel preparation & Immediate feedback on results & Pathology results: how and by whom \\
\hline & Instructions & Printed copy of report & Follow-up tests and appointments \\
\hline & Format (written, video, in person) & Discharge instructions & Ability to contact someone for advice \\
\hline & Who providing (doctor, nurse, clerk) & Family members kept advised & $\begin{array}{l}\text { Adequacy of communication with referring } \\
\text { physician }\end{array}$ \\
\hline & Endoscopy & & Comments to future patients \\
\hline & Nature of procedure and risks & & Recommendations to potential patients \\
\hline & Test characteristics & & \\
\hline & Alternatives & & \\
\hline & Endoscopist scorecard & & \\
\hline & Facility scorecard & & \\
\hline
\end{tabular}

\section{GP General practitioner}

\section{REFERENCES}

1. Rabeneck L, Paszat LF, Saskin R. Endoscopist specialty is associated with incident colorectal cancer after a negative colonoscopy. Clin Gastroenterol Hepatol 2010;8:275-9.

2. Tamblyn RM, McLeod PJ, Abrahamowicz M, et al. Questionable prescribing for elderly patients in Quebec. CMAJ 1994;150:1801-9.

3. Shah HA, Paszat LF, Saskin R, et al. Factors associated with incomplete colonoscopy: A population-based study. Gastroenterology 2007;132:2297-303.

4. Institute of Medicine (IOM). Crossing the Quality Chasm: A New Health System for the 21st Century: A New Health System for the 21st Century. Washington, DC: National Academy Press; 2001.

5. Institute of Medicine. To Err Is Human: Building a Safer Health System. Washington, DC: National Academies Press; 2000.

6. Institute of Medicine (IOM). Medicare: A strategy for quality assurance. Washington, DC: 1990.

7. Donabedian A. The role of outcomes in quality assessment and assurance. QRB Qual Reev Bull 1992;18:356-60.

8. Donabedian A. Quality assurance. Structure, process and outcome. Nurs Stand 1992;7(11Suppl QA):4-5.

9. Sofaer S, Crofton C, Goldstein E, et al. What do consumers want to know about the quality of care in hospitals? Health Serv Res 2005;40:2018-36.

10. Institute of Medicine. Measuring the Quality of Health Care. Washington, DC: National Academy of Sciences; 1999.

11. Sofaer S, Firminger K. Patient perceptions of the quality of health services. Annu Rev Public Health 2005;26:513-59.

12. Valori R, Sint Nicolaas J, de Jonge V. Quality assurance of endoscopy in colorectal cancer screening. Best Pract Res Clin Gastroenterol 2010;24:451-64.

13. Armstrong D, Barkun AG, Chen Y, et al. Access to specialist gastroenterology care in Canada: The Practice Audit in Gastroenterology (PAGE) wait times program. Can J Gastroenterol 2008;22:155-60.

14. Leddin D, Armstrong D, Barkun ANG, et al. Access to specialist gastroenterology care in Canada: Comparison of wait times and consensus targets. Can J Gastroenterol 2008;22:161-7.

15. Armstrong D, Enns R, Ponich T, et al. Canadian credentialing guidelines for endoscopic privileges: An overview. Can J Gastroenterol 2007;21:797-801.

16. Romagnuolo J, Enns R, Ponich T, et al. Canadian credentialing guidelines for colonoscopy. Can J Gastroenterol 2008;22:17-22.
17. Kappelman MD, Dorn SD, Peterson E, et al. Quality of care for gastrointestinal conditions: A primer for gastroenterologists. Am J Gastroenterol 2011;106:1182-7.

18. Rex DK, Petrini JL, Baron TH, et al. Quality indicators for colonoscopy. Am J Gastroenterol 2006;101:873-85.

19. Armstrong D, Hollingworth R, Gardiner T, et al. Practice Audit in Gastroenterology (PAGE) program: A novel approach to continuing professional development. Can J Gastroenterol 2006;20:405-10.

20. Armstrong D, Hollingworth R, MacIntosh D, et al. Point-of-care, peer-comparator colonoscopy practice audit: The Canadian Association of Gastroenterology Quality Program - Endoscopy. Can J Gastroenterol 2011;25:13-20.

21. Sewitch MJ, Abrahamowicz M, Dobkin PL, et al. Measuring differences between patients' and physicians' perceptions: The Patient-Physician Discordance Scale. J Behav Med 2003;26:245-64.

22. Dobkin PL, De Civita M, Bernatsky S, et al. Patient-physician discordance in fibromyalgia. J Rheumatol 2003;30:1326-34.

23. Friedman AL. Secret shopper. JAMA 2011;304:2103-4.

24. Glaser BG, Strauss AL. The Discovery of Grounded Theory: Strategies for Qualitative Research. New York: Aldine de Gruyter; 1967.

25. Hilsden R, Rostom A, Dube C, et al. Development and implementation of a comprehensive quality assurance program at a community endoscopy facility. Can J Gastroenterol 2011;25:547-54.

26. McLachlan S, Clements A, Austoker J. Patients' experiences and reported barriers to colonoscopy in the screening context - a systematic review of the literature. Patient Educ Couns 2011.

27. Sewitch MJ, Gong S, Dube C, et al. A literature review of quality in lower gastrointestinal endoscopy from the patient perspective. Can J Gastroenterol 2011;25:681-5.

28. Wensing M, Elwyn G. Improving the quality of health care: methods for incorporating patients' views in health care. BMJ 2003;326:877-9.

29. Faivre J, Bouvier A-M, Bonithon-Kopp C. Epidemiology and screening of colorectal cancer. Best Pract Res Clin Gastroenterol 2002;16:187-99.

30. Ries LAG, Wingo PA, Miller DS, et al. The annual report to the nation on the status of cancer, 1973-1997, with a special section on colorectal cancer. Cancer 2000;88:2398-424.

31. Ferguson RJ, Paulin M, Leiriao E. Loyalty and positive word-ofmouth: Patients and hospital personnel as advocates of a customercentric health care organization. Health Mark Q 2006;23:59-77. 


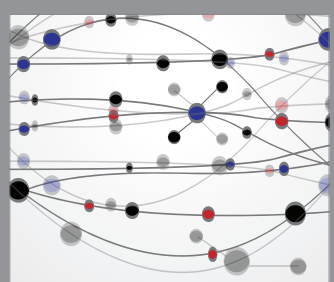

The Scientific World Journal
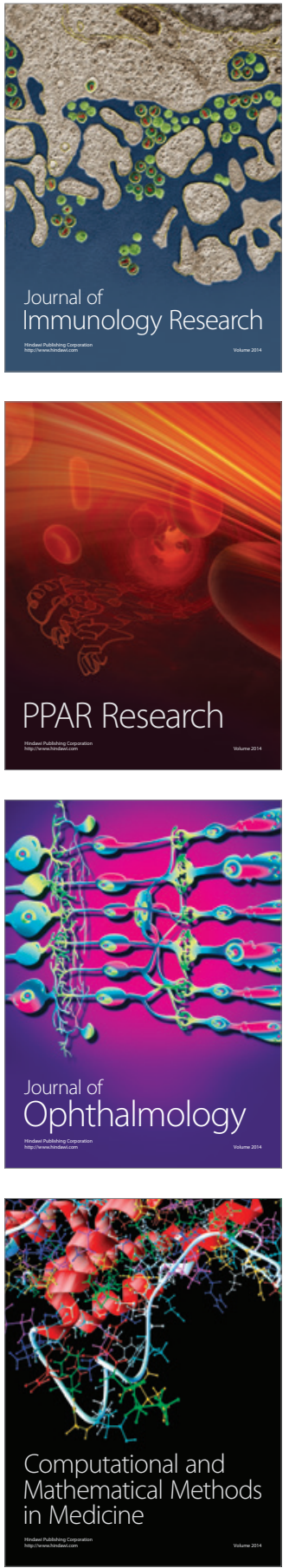

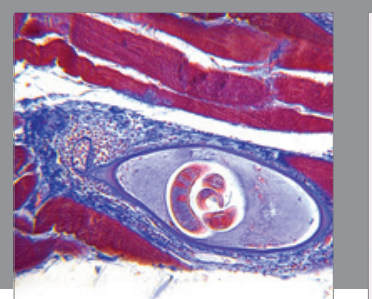

Gastroenterology Research and Practice

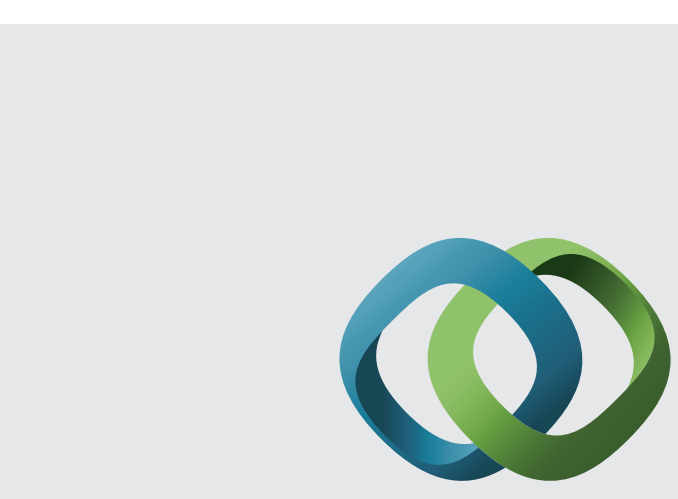

\section{Hindawi}

Submit your manuscripts at

http://www.hindawi.com
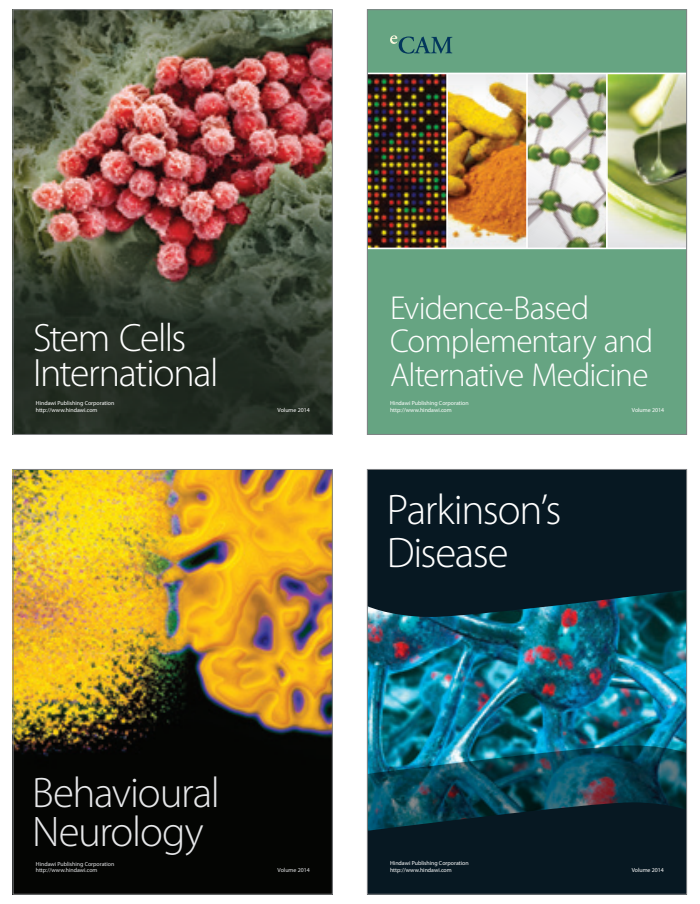
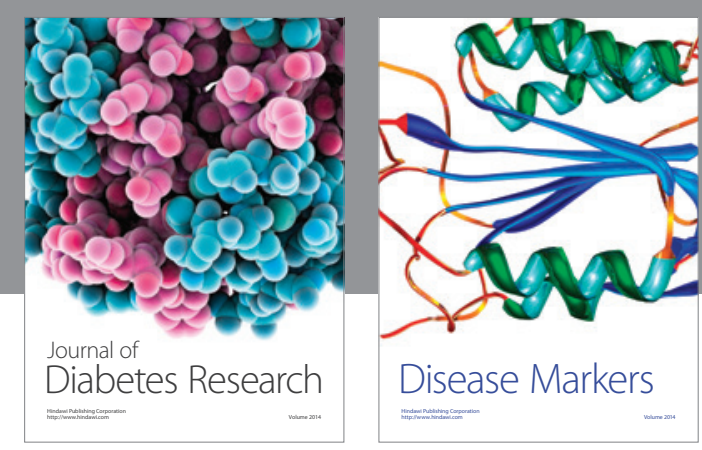

Disease Markers
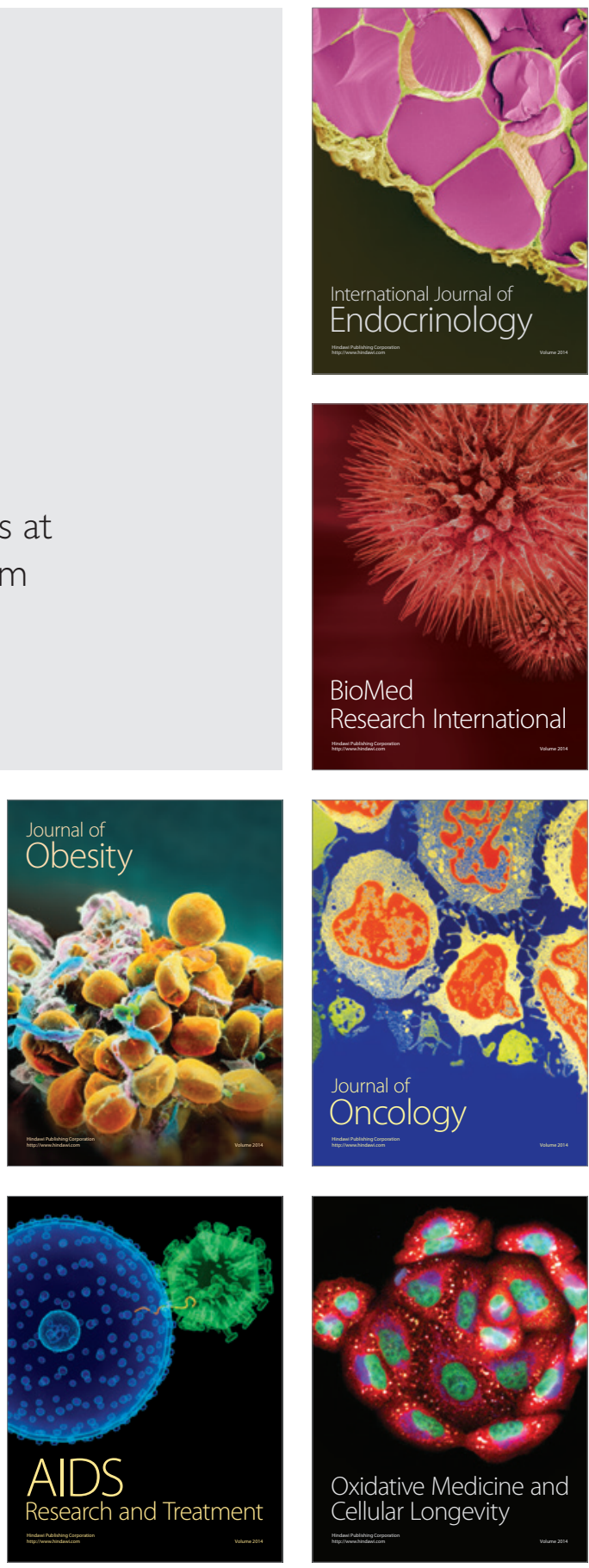